\title{
VARIATIONS IN THE COURSE OF RHEUMATOID ARTHRITIS
}

\author{
BY \\ P. E. BROWN AND J. J. R. DUTHIE \\ From the Department of Social and Industrial Medicine, The University, Sheffield, \\ and \\ the Rheumatic Unit, Northern General Hospital, Edinburgh
}

In previous papers (Duthie, Thompson, Weir, and Fletcher, 1955; Duthie, Brown, Knox, and Thompson, 1957), the course of a group of patients with rheumatoid arthritis after admission to hospital was described. Certain features of the disease with a bearing on prognosis were discussed. Changes in functional capacity and disease activity were considered for the group as a whole and no attempt was made to trace the course taken by individual cases. The figures reproduced in Tables I and II represent the overall status of the group and do not distinguish between cases more or less permanently in a particular grade and cases with a fluctuating course who happened to be in that grade at the time of assessment. The results could equally well be derived from a group in which every member was pursuing an erratic course as from a group in which the majority were steadily improving or deteriorating.

The present communication is concerned with the types of course pursued by individual patients and particularly with the question of whether an appreciable number of cases showed a tendency towards permanent recovery or towards permanent disablement.

A complete account of the group and the methods of assessment will be found in earlier reports (Duthie and others, 1955, 1957). Functional capacity and disease activity were determined on admission to hospital, on discharge, and at three subsequent assessments approximately 2 years apart. Four functional grades were used:

Grade I. Fitness for all normal activities;

Grade II. Moderate restriction of function;

Grade III. Marked restriction.

Grade IV. Confined to bed or chair.

Disease activity was assessed as very active, moderately active, or inactive, according to the E.S.R., the haemoglobin level, the presence of signs of inflammation in the joints, and the degree of systemic disturbance.

Changes in functional capacity and disease activity for the group as a whole are shown in Tables I and II.

There was a slight falling off in functional capacity between the first and second and second and third

TABLE I

FUNCTIONAL CAPACITY ON ADMISSION, ON DISCHARGE, AND AT SUCCESSIVE FOLLOW-UP ASSESSMENTS

\begin{tabular}{|c|c|c|c|c|c|c|c|c|c|c|}
\hline \multirow{2}{*}{\multicolumn{4}{|c|}{ Time of Estimation }} & \multirow{2}{*}{$\begin{array}{l}\text { No. of } \\
\text { Cases }\end{array}$} & \multicolumn{6}{|c|}{ Functional Grades (per cent. of total) } \\
\hline & & & & & I & II & III & IV & $\mathbf{I}+\mathbf{I I}$ & III + IV \\
\hline $\begin{array}{l}\text { Admission } \\
\text { Discharge . . . } \\
\text { First Assessment } \\
\text { Second Assessment } \\
\text { Third Assessment }\end{array}$ & $\begin{array}{l}\cdots \\
\cdots \\
\cdots \\
\cdots\end{array}$ & $\begin{array}{l}\cdots \\
\cdots \\
\cdots \\
\cdots\end{array}$ & \begin{tabular}{l|}
$\cdots$ \\
$\cdots$ \\
$\cdots$ \\
$\cdots$
\end{tabular} & $\begin{array}{l}282 \\
282 \\
282 \\
258 \\
247\end{array}$ & $\begin{array}{l}\overline{11 \cdot 3} \\
28 \cdot 4 \\
27 \cdot 9 \\
23 \cdot 5\end{array}$ & $\begin{array}{l}35 \cdot 4 \\
64 \cdot 2 \\
44 \cdot 0 \\
42 \cdot 2 \\
40 \cdot 5\end{array}$ & $\begin{array}{l}42 \cdot 6 \\
24 \cdot 1 \\
25 \cdot 1 \\
23 \cdot 6 \\
26 \cdot 7\end{array}$ & $\begin{array}{r}22 \cdot 0 \\
0 \cdot 4 \\
2 \cdot 5 \\
6 \cdot 2 \\
9 \cdot 3\end{array}$ & $\begin{array}{l}35 \cdot 4 \\
75 \cdot 5 \\
72 \cdot 3 \\
70 \cdot 1 \\
64 \cdot 0\end{array}$ & $\begin{array}{l}64 \cdot 6 \\
24 \cdot 5 \\
27 \cdot 6 \\
29 \cdot 9 \\
36 \cdot 0\end{array}$ \\
\hline
\end{tabular}

TABLE II

DISEASE ACTIVITY ON ADMISSION, ON DISCHARGE, AND AT SUCCESSIVE FOLLOW-UP ASSESSMENTS

\begin{tabular}{|c|c|c|c|c|c|c|c|}
\hline \multirow{2}{*}{\multicolumn{4}{|c|}{ Time of Estimation }} & \multirow{2}{*}{ No. of Cases } & \multicolumn{3}{|c|}{ Disease Activity (per cent. of total) } \\
\hline & & & & & Very Active & Moderately Active & Inactive \\
\hline $\begin{array}{l}\text { Admission } \quad \text {. } \\
\text { Discharge } \quad \ldots \\
\text { First Assessment } \\
\text { Second Assessment } \\
\text { Third Assessment }\end{array}$ & $\begin{array}{l}\cdots \\
\cdots \\
\cdots \\
\cdots\end{array}$ & $\begin{array}{l}\cdots \\
\cdots \\
\cdots \\
\cdots\end{array}$ & $\begin{array}{l}\cdots \\
\cdots \\
\cdots \\
\cdots\end{array}$ & $\begin{array}{l}282 \\
282 \\
282 \\
258 \\
247\end{array}$ & $\begin{array}{r}26 \cdot 2 \\
5 \cdot 0 \\
3 \cdot 5 \\
12 \cdot 0 \\
1 \cdot 2\end{array}$ & $\begin{array}{l}63 \cdot 5 \\
59 \cdot 2 \\
65 \cdot 6 \\
61 \cdot 2 \\
69 \cdot 6\end{array}$ & $\begin{array}{l}10 \cdot 3 \\
35 \cdot 8 \\
30 \cdot 9 \\
26 \cdot 8 \\
29 \cdot 2\end{array}$ \\
\hline
\end{tabular}


TABLE III

CHANGE OF FUNCTIONAL GRADES BETWEEN SUCCESSIVE ASSESSMENTS (PER CENT. OF TOTAL)

\begin{tabular}{|c|c|c|c|c|c|c|c|}
\hline & $\begin{array}{l}\text { hanges in } \\
\text { Grade }\end{array}$ & & & $\begin{array}{l}\text { Admission to } \\
\text { Discharge }\end{array}$ & $\begin{array}{l}\text { Discharge to } \\
\text { First Assessment }\end{array}$ & $\begin{array}{c}\text { First to } \\
\text { Second Assessment }\end{array}$ & $\begin{array}{l}\text { Second to } \\
\text { Third Assessment }\end{array}$ \\
\hline $\begin{array}{l}\text { Remaining in } \\
\text { Upgraded } \\
\text { Downgraded }\end{array}$ & $\begin{array}{l}\text { Same Grade } \\
\ldots \\
\ldots\end{array}$ & $\begin{array}{l}\cdots \\
\cdots\end{array}$ & $\begin{array}{l}\ldots \\
\cdots \\
\cdots\end{array}$ & $\begin{array}{c}39 \cdot 8 \\
60 \cdot 2 \\
-\end{array}$ & $\begin{array}{l}51 \cdot 4 \\
32 \cdot 0 \\
16 \cdot 6\end{array}$ & $\begin{array}{r}70 \cdot 4 \\
9 \cdot 3 \\
20 \cdot 2\end{array}$ & $\begin{array}{r}78 \cdot 6 \\
3 \cdot 2 \\
18 \cdot 2\end{array}$ \\
\hline
\end{tabular}

assessments. The number of cases graded as inactive increased between admission to hospital and discharge and decreased slightly at the later assessments.

\section{Fluctuations in Functional Capacity}

The cases in a particular grade at the time of assessment were made up of those in that grade at the previous assessment and those arriving from other grades in the interval between assessments. The proportion of cases remaining in the same grade from one assessment to another gives an indication of the stability of the group. 56 per cent. of the cases remained in the same functional grade at the three assessments following discharge, and 79 per cent. remained either in Grades I or II or in Grades III or IV. This indicates a considerable degree of stability, since in fluctuations due solely to chance only 6 per cent. would be expected to remain in the same grade. Details of these movements are given in Table III.

There was an increasing degree of stability between the later assessments which is accounted for by a decline in the number of patients moving into higher grades, whereas the number deteriorating stayed much the same.

It might be expected that stability would vary in some way with the severity of the disability, but the percentage of patients discharged in Grade I, who were in the same grade at the three later assessments, was $56 \cdot 6$, compared with $56 \cdot 2$ per cent. of those discharged in Grade II and 54.5 per cent. of those discharged in Grades III and IV, although the grade at the three assessments was not necessarily the one in which the patient was discharged.

A complete account of all changes in grade between discharge from hospital and the third assessment (mean interval $67 \cdot 4$ months) is given in Table IV (opposite).

247 patients followed 51 different courses out of 256 possible ways in which a case might move through four grades over four assessments. The ten most common courses, illustrated in Table $\mathrm{V}$, account for 67 per cent. of all patients.
Table $\mathrm{V}$ shows that the most common course followed by patients discharged in Grade II was to remain in this grade until the third assessment (45 patients). The next most common was to improve after discharge so that the patient was placed in Grade I and remained in this grade at subsequent assessments (35 patients). A small number improved temporarily but were returned to Grade II at the second assessment (13 patients). The remainder were relegated to Grade III at the first (10 patients), second (11 patients), or third assessment (12 patients). Only six of 24 patients discharged in Grade III were subsequently upgraded. Of seventeen patients discharged in Grade I, nine remained in that grade and eight were subsequently relegated to Grade II.

TABLE V

THE TEN COURSES MOST COMMONLY TAKEN BETWEEN DISCHARGE AND THE THIRD ASSESSMENT

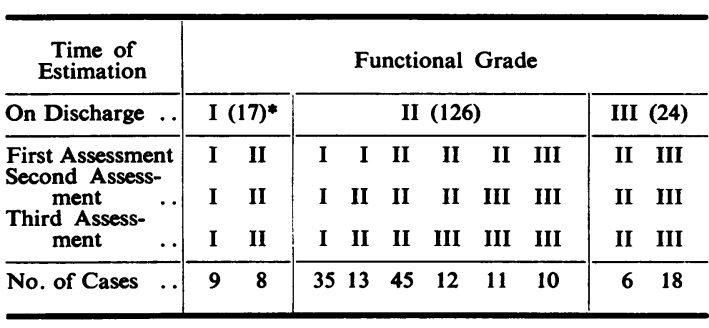

- Numbers of patients shown in brackets.

\section{Disease Activity}

Although 55 per cent. of the patients remained in the same grade of disease activity at the three follow-up assessments, this figure does not indicate a degree of stability comparable with that found in $N$ respect of functional capacity. A large number of patients remained within the wide limits used to define the grade "moderately active". 37 (15 per cent.) remained inactive throughout the three assessments, showing that half of the $29 \cdot 2$ per cent. of patients who were inactive at the third assessment had been active at one of the previous assessments. Only seven out of 28 patients rated as 
TABle IV

VARIATIONS IN FUNCTIONAL STATUS BETWEEN DISCHARGE AND THE THIRD ASSESSMENT IN 247 PATIENTS

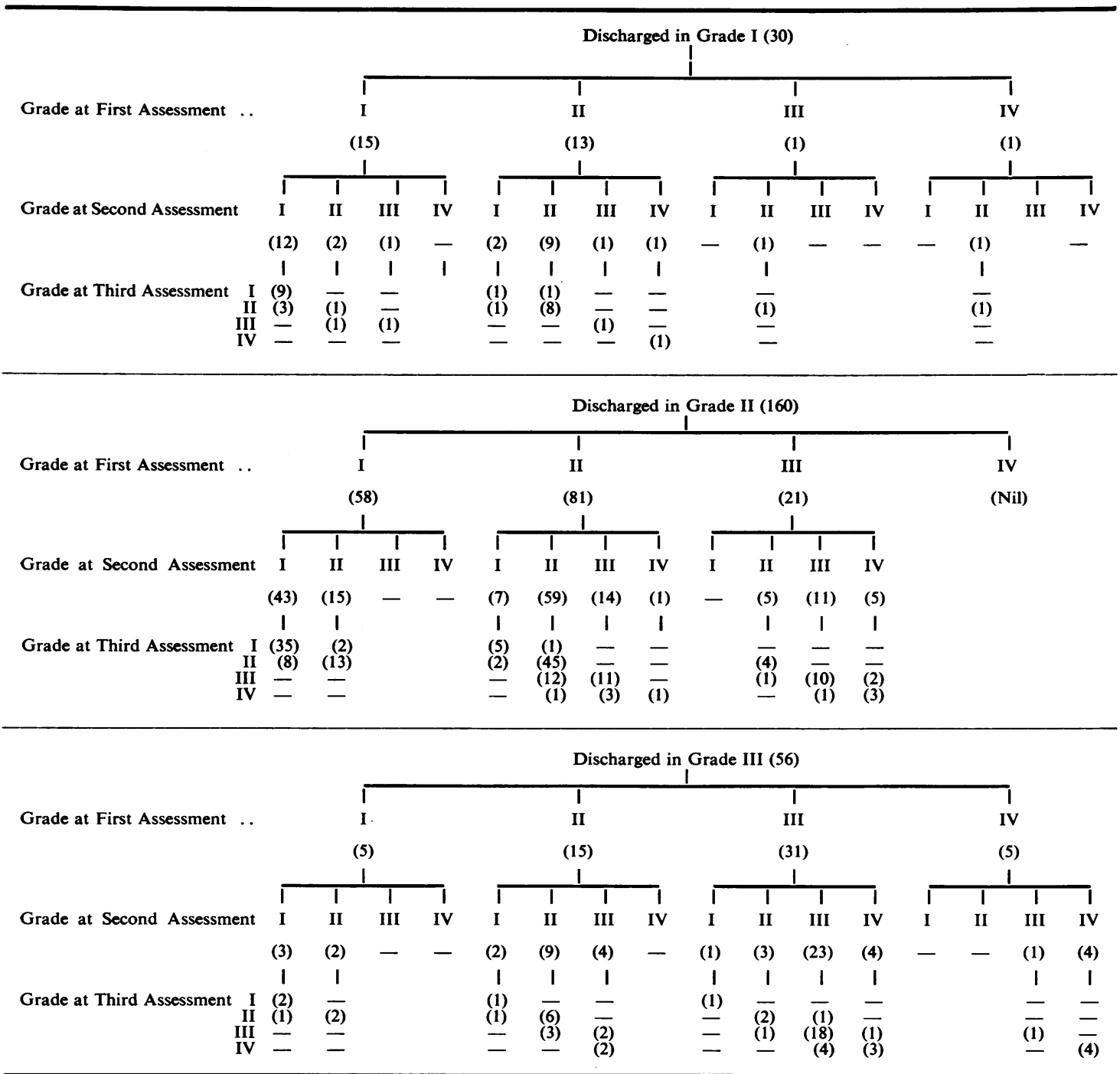

NoTE: One case was discharged in Grade IV and was placed in Grade III at each of the later assessments.

inactive on admission remained inactive throughout the period of the survey, indicating that less than 3 per cent. of the whole group showed no signs of activity at any examination. No case remained very active over the three assessments and no case classed as inactive at any time ever became very active.

\section{Characteristics of the Main Types}

When the functional course was examined in detail, it was found that patients could be divided into four main groups:

(1) 46 cases remained in functional Grade $I$ at all three assessments.

(2) 102 cases remained in Grade II or moved between Grades I and II, indicating the retention of a reasonable degree of functional efficiency.

(3) 50 cases remained in Grades III and IV at the three assessments, representing the more chronically disabled. 
(4) The remaining cases showed greater changes in functional capacity: 39 moved downwards from Grades I or II into Grades III or IV, and nine moved upwards from Grades III or IV into Grades I or II.

The 46 cases with the most favourable outcome were examined to see whether they could be distinguished from those with a less favourable prognosis. Table VI shows a comparison in respect of certain features of this group with the most disabled group represented by those found in Grades III or IV at the last two assessments.

The Table confirms the favourable prognostic significance of admission to hospital within one year of the onset of symptoms. All cases who were classed as having run a rapidly progressive course were admitted within one year of the onset. Nineteen of these patients were placed in Grade I at all three assessments after discharge, accounting for 41 per cent. of the group ultimately running the most benign course. The other features examined appear to be of less significance. In particular, E.S.R. on admission and age at onset show the least close relationship with subsequent progress. It is of interest to note that a proportion of patients with some of the less favourable prognostic features, such as duration of disease over 5 years before admission, insidious onset and slowly progressive course, and moderate to marked functional impairment on admission, proved capable of attaining and remaining in Grade I.

\section{Functional Capacity and Disease Activity}

When functional capacity is related to disease activity, it becomes obvious that ability to perform all normal duties may be retained even when signs of activity are present. At the second assessment, for example, just under 50 per cent. of the cases in Grade I were assessed as inactive. However, in Grade II only 20 per cent. were inactive, and in Grades III and IV only 17 per cent. When functional capacity and disease activity were compared to see how many of the 46 patients who remained in functional Grade I throughout the three assessments were also inactive at those assessments, it was found that only eighteen filled this double qualification; thus only 7 per cent. of the 247 patients had suffered no impairment of function and had shown no evidence of disease activity since discharge from hospital.

\section{Discussion}

An analysis of the functional status and signs of disease activity in a group of patients with rheumatoid arthritis, at intervals after discharge from hospital, gives no information as to the course pursued by the individuals making up the group. Conclusions drawn from such a study only indicate general trends and give little help in forecasting the course in a particular case. For this reason an analysis of fluctuations in functional status and signs of disease activity in each patient was considered essential if a true picture of the course of this disease was to be provided. It becomes apparent from theo results now presented that there is a general ten dency for patients to maintain approximately the same functional level over fairly long periods after treatment in hospital. The two main groups of patients are those who fluctuate between the two upper functional grades and those who become and

TABLE VI

COMPARISON OF INCIDENCE OF CERTAIN FEATURES IN PATIENTS WITH LITTLE IMPAIRMENT OF FUNCTION AND IN THOSE SEVERELY DISABLED

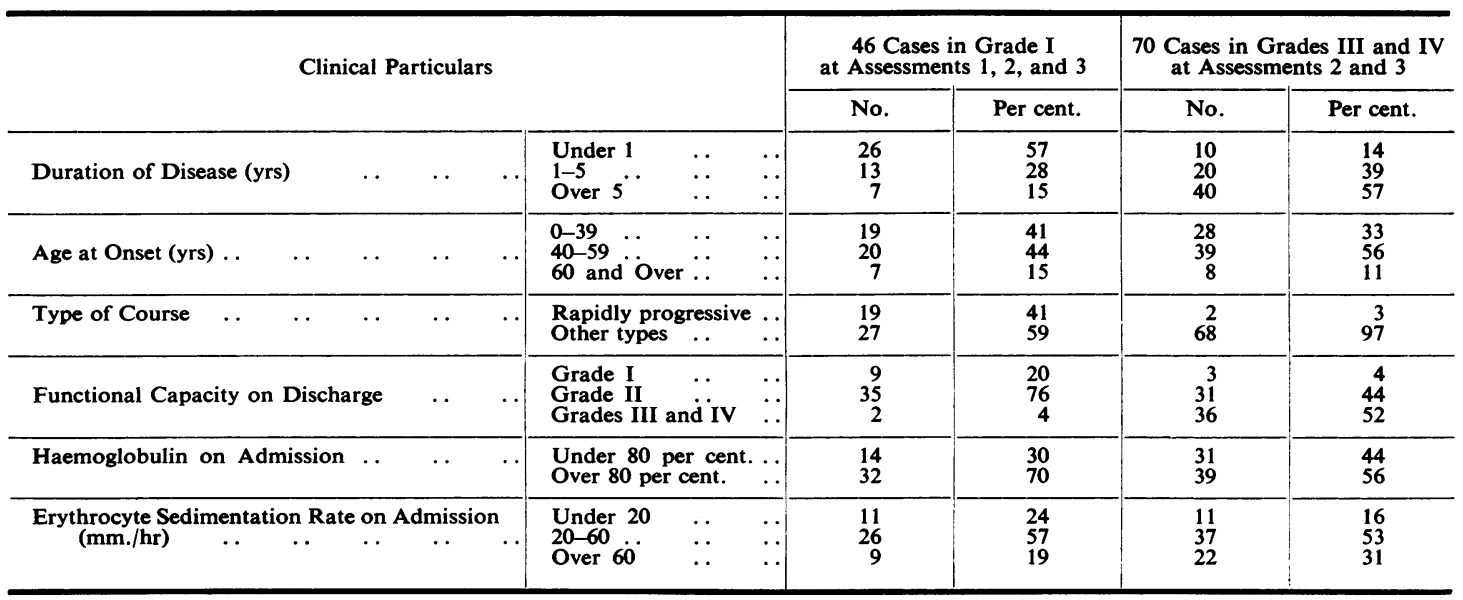


remain more severely disabled. With the passage of time, a small number of patients who have initially run a favourable course drift into the more disabled group. There is little evidence that those patients running the most benign course can be regarded as cured. Even of those showing no functional impairment throughout the period of observation, about 50 per cent. continue to show some signs of active disease. Only 7 per cent. of patients in Grade $I$ at all three assessments after discharge were also rated as inactive at each of these examinations. It has often been stated that rheumatoid arthritis is a disease which tends to become inactive or "burnt out" in its later stages. No support for this contention has emerged from this investigation. A high proportion of those patients who had become severely disabled over the years continued to show signs of active disease. The majority of the group were rated as moderately active at every examination. This is by no means incompatible with unimpaired function.

A comparison of the incidence of certain features in patients with minimal disability and in those severely disabled has confirmed the relatively good prognosis of patients admitted within one year of the onset of symptoms, particularly if the disease has run a progressive course up to the time of admission to hospital. Other features such as age at onset, and haemoglobin and erythrocyte sedimentation rate on admission, seem to have much less bearing on the subsequent course of the disease.

\section{Conclusions}

(1) There seems to be a general tendency for cases to remain at approximately the same functional level after treatment in hospital. The two main groups of patients are made up of those who fluctuate between a very little and moderate, but not incapacitating, disability, and those who become and remain severely disabled. As time goes on, a small proportion of cases from the more favourable group drifts into the disabled group.

(2) There is little evidence to suggest that patients running the most benign course can be regarded as cured. Of those showing no disability throughout the period of observation, half continued to show signs of disease activity. Only 7 per cent. of the total number of patients had retained full functional capacity and shown no signs of disease activity following discharge from hospital.

(3) A high proportion of those who were severely disabled still showed signs of disease activity. There was no evidence that any of these cases had "burned themselves out".

(4) The group with the best prognosis comprised patients who had run a progressive course since the onset and who were admitted to hospital within one year.

\section{Summary}

Analysis of functional status and disease activity in a group of patients with rheumatoid arthritis at intervals after discharge from hospital gives no information as to the course pursued by individual patients. The present communication comprises a detailed study of the types of course pursued by 247 patients with the purpose of discovering whether an appreciable number of patients shows a tendency towards permanent recovery or permanent disablement. The following conclusions have been reached:

(1) There appears to be a general tendency for patients to remain at approximately the same functional level for fairly long periods after treatment in hospital. 56 per cent. of the patients remained in the same functional grade at the three assessments after discharge, and 79 per cent. remained either in Grades I or II or in Grades III or IV. As time goes on a small proportion of cases from the more favourable group drifts into the disabled group.

(2) There is little evidence to suggest that patients running the most favourable course can be regarded as cured. Of those without disability throughout the period of observation, half continued to show signs of disease activity. Nor is there any evidence that in severely disabled patients the disease has "burned itself out". A high proportion continued to show signs of activity.

(3) The group with the best prognosis consisted of patients who had run a progressive course since the onset of symptoms and had been admitted to hospital within one year of the onset.

During the period when this work was done, the Rheumatic Unit was in receipt of grants from the Nuffield Foundation, the Medical Research Council, and Boots Pure Drug Company, Limited.

\section{REFERENCES}

Duthie, J. J. R., Brown, P. E., Knox, J. D E., and Thompson, M (1957). Ann. rheum. Dis., 16, 411.

Thompson, M., Weir, M. M., and Fletcher, W. B. (1955). Ibid., 14, 133.

Variations dans l'évolution de l'arthrite rhumatismale RÉsumé

L'analyse périodique de l'état fonctionnel et et de l'activité morbide d'un groupe de rhumatisants après leur sortie de l'hôpital donne peu de renseignements sur l'évolution des cas individuels. La communication présente offre une étude détaillée des types évolutifs de l'arthrite rhumatismale dans 247 cas; on s'y efforce de trouver si un nombre appréciable de ces cas évolue vers la guérison permanente ou une incapacité permanente. 
On est arrivé à des conclusions suivantes:

(1) En général, les malades tendent à se maintenir à un niveau fonctionnel à peu près constant pendant des périodes assez prolongées après leur sortie de l'hôpital. Trois évaluations après le renvoi de l'hôpital ont montré que $56 \%$ des malades se maintenaient dans le même groupe fonctionnel et que $79 \%$ demeuraient soit dans le Grade I ou II soit dans le Grade III ou IV. Avec le temps, une petite proportion des cas du groupe favorable passe au groupe des infirmes.

(2) Rien n'indique qu'un malade dont l'arthrite suit un cours très favorable peut être regardé comme guéri. La moitié de celıx sans signes d'incapacité continuaient a accuser des signes d'activité morbide pendant toute la période d'observation. On ne trouve pas, non plus, que la maladie "s'eteint" chez ceux qui souffrent d'une sévère incapacité, car beaucoup d'entre eux accusent des signes d'activité morbide.

(3) Le groupe avec le meilleur pronostic consistait de malades avec une évolution progressive dès le début et admis à l'hôpital en dedans d'un an du début.

\section{Variaciones en la evolución de la artritis reumatoide}

\section{SUMARIO}

El análisis del estado funcional y de la actividad mórbosa de un grupo de enfermos con artritis reumatoide a intervalos de tiempo después de su salida del hospital ofrece poca información sobre la evolución de los casos 3 individuales. La comunicación presente ofrece un estudio detallado de los tipos evolutivos de la artritis reumatoide en 247 casos; se trata aquí de haller si un número apreciable de estos casos camina hacia una cura $\stackrel{S}{\rightarrow}$ permanente o una invalidez permanente. He aquí las conclusiones:

(1) De una manera general los enfermos tienden a $\frac{\bar{O}}{\bar{\omega}}$ mantenerse a un nivel funcional aproximadamente $\vec{T}$ constante durante períodos prologados después de haber $\mathbb{Q}$ quitado el hospital. Tres valoraciones después de darles de alta muestran que un $56 \%$ de los enfermos se mantiene $\omega$ en el mismo grupo funcional y que un $79 \%$ queda sea $\vec{\circ}$ en el Grado I o II y en el Grado III o IV. Con el tiempo una pequeña proporción de los casos del grupo favorable pasa al grupo de los incapacitados.

(2) No hay datos indicando que un enfermo, cuya artritis sigue un curso muy favorable, puede considerarse ? curado. La mitad de los que no acusaron signos de $\vec{V}$ incapacidad durante todo el período de observación, i siguieron mostrando signos de actividad mórbosa. $\omega$ Tampoco se comprobó que la enfermedad "se apaga" ஸु en los severamente incapacitados, ya que muchos acusaron signos de actividad morbosa.

(3) El grupo con el mejor pronóstico consistió de enfermos con una evolución progresiva desde el comienzo de la enfermedad y hospitalizados dentro de un año. 